\title{
Current Status and Prospects of China's Hainan Free Trade Zone
}

\author{
Jiexuan Zhou $^{1, *}{ }^{\text {Jingyi Dai }}{ }^{1}$ Zhuyu Liang $^{1}$ \\ ${ }^{1}$ Yancheng Teachers University, Yancheng, Jiangsu 222400, China \\ *Corresponding author. Email: wanglj432@126.com
}

\begin{abstract}
Reform and opening up is an important policy for the development of modern China's economy, and opening up to the outside world is the direction that has always been adhered to. In 2018, the establishment of a free trade pilot zone on the whole island of Hainan was mentioned as a policy. This reflects the concern and attention of the Party Central Committee to Hainan, and it is also a historic breakthrough in China's opening up to the outside world. Hainan has been transformed from a special economic zone to a free trade zone, giving full play to the location advantages of Hainan Island's independent geographic unit and the overall advantages of the island's pilot project, and plays a very important role in the high-quality development of the future economy in the province. This article expounds the basic situation of Hainan Free Trade Zone by consulting relevant materials, and points out the innovation practice of Hainan Free Trade Zone. At the same time, it sorts out the advantages and disadvantages of the development of Hainan Free Trade Zone, and on this basis, discusses the operation prospects and development trends of Hainan Free Trade Zone.
\end{abstract}

Keywords: Hainan Free Trade Zone, economic development, prospect

\section{INTRODUCTION}

"Opening up to the outside world" is a basic national policy of China. Opening up is a secret to China's economic take-off and a magic weapon for Hainan to develop its economy. With the deepening of the pace of opening up, foreign trade has become an indispensable part of improving economic efficiency, and it has become an important industry, which helps capital accumulation to promote the economic development of the country or region. On April 13, 1988, Hainan Province and Hainan Special Economic Zone were established at the same time, and it is the only provincial-level special economic zone. The overall level of Hainan Special Economic Zone is relatively backward. The economic development is dominated by the primary industry. The emerging Internet industry started late and the industrial process is slow. The country's special opening policy on Hainan has enriched the history of foreign economic relations and trade. In 1990, the State Council approved that foreigners can apply for entry visas in Haikou or Sanya. In 2000, with the approval of the State Council, Hainan began to implement the visa-free policy for the 21nation tour group. In April 2007, the central government officially proposed to expand tourism opening and promote the construction of an international tourist island. In 2009, the state explicitly granted visa-free policies to 26 countries in Hainan
Province. At present, the coverage of the visa-free policy has been further expanded. In 2015, Hainan took the advantage of the Boao Forum for Asia to build a communication channel between the mayors of ChinaASEAN Province and form a consensus on economic aspects through mutual benefit and cooperation, which enhanced the economic and trade exchanges between Hainan and ASEAN countries. In 2018, General Secretary Xi Jinping announced the establishment of the Hainan Island Free Trade Zone on the occasion of the 30th anniversary of the establishment of the Hainan Special Economic Zone. He supported the gradual exploration of the Free Trade Zone (Port) development policies and systems, expanded the degree of openness, and attracted foreign and foreign companies to enter. We will vigorously develop the advantages of the region and promote the economic development of the Hainan Free Trade Zone.

The construction of a free trade zone with Chinese characteristics can effectively promote China's highlevel opening to the outside world. At the same time, it can also promote the further development of Hainan's economy and thus achieve a balanced development of China's economy. The island economy formed in Hainan is the most qualified for exploring free trade. It is an open mode breakthrough and is the best time for the present. By then, this will inevitably attract the entry of foreign investment, talents, currency, and production materials, and inject a strong impetus into 
Hainan's development, and bring opportunities for Hainan's economic development. At the same time, China releases the most powerful signal to the world "The open door will only open wider and wider." This article analyzes the development status of Hainan Free Trade Zone and clarifies its development advantages and existing deficiencies. This is of great significance for analyzing the development prospects of Hainan Free Trade Zone and promoting China's high-level external development.

\section{THE DEVELOPMENT STATUS OF HAINAN Free Trade ZONE}

\section{A. Basic information of Hainan Free Trade Zone}

Looking back at the policy adjustments since Hainan's establishment of the province for more than 30 years, policy-oriented industrial trade has also experienced: the gradual evolution of general agricultural trade, processing trade, and tourism service trade. In the 30 years of continuous development, the commodity structure and business entities of Hainan's foreign trade have also undergone fundamental changes. At present, Hainan's foreign trade imports are mainly resource-based commodities and high-tech products, and export of agricultural products leads the country; in 2018, there were 167 new foreign-invested enterprises in the province, an increase of 80 over the previous year; with the acceleration of trade openness and freedom, Haikou Free Trade Zone and Yangpu Economic Development Zone have been approved, and the opening of key ports in the province has been deepened. The new system of Hainan Province's export-oriented economy will be displayed in a leap forward.

On the first anniversary of the establishment of the Hainan Free Trade Zone, as of April 16, 2019, a total of 378 projects were started, with a total investment of 185.7 billion RMB; 195 centralized contracted projects with a total investment of 285.9 billion RMB. The first year of foreign trade import and export volume increased by nearly $50 \%$ year-on-year. Hainan Construction Free Trade Zone's foreign trade import and export, out-of-island duty-free sales, inbound and outbound yachts, parallel car imports and other indicators rose significantly. From the current results, Hainan has made a lot of efforts in terms of personnel, goods, and free flow of funds.

\section{B. Innovation practice in Hainan Free Trade Zone}

1) Market access: Hainan launched the "Hainan Province Optimization of Business Environment Action Plan (2018-2019)" forty measures. Through the pilot establishment of foreign capital and the further acceleration of the establishment of a new industrial system, the business environment has been comprehensively improved. At the same time, the volume and quality of Hainan's tourism service industry has obvious advantages in South China. Therefore, the open policy on tourism services is expected to become a new opportunity for foreign investment, in September 2018, the Guide for the Approval and Filing of Foreign Investment Projects implemented by Hainan Province fully implemented the pre-entry national treatment and the new negative list management model, the 2018 new edition of the guide on the negative list has been reduced from 190 to 45 in the 2013 edition, which provides institutional convenience for the development of enterprises that come to Hainan, and actively conducts innovative research in the FTA area, and 22 key researches. The project was initiated. In the face of opportunities, Hainan Province has issued a series of policies for international companies to attract international SMEs, using international recruitment platforms to make good use of national parks, outlying island service centers, etc, focusing on internationalization to attract high-end elements, starting from traditional projects and attracting more important factors, especially some functional platform projects around the South China Sea trade and Hainan's fishery agricultural resources development will be strongly attracted. In 2018, more than 20 foreignfunded projects such as Singapore's Temasek, British Merlin Entertainment Group and US Three-Five Global Group were successfully introduced, which has achieved remarkable results in promoting service industry upgrading and opening up. In addition, the Hainan Free Trade Zone has also landed an industrial catalogue that encourages foreign investment. The Hainan Provincial Development and Reform Commission is currently working with the Municipal Investment Promotion Committee to develop an industrial catalogue that encourages foreign investment. The industry listed in the catalogue can enjoy the related preferential policiesformulated byrelevant industry authorities.

2) Trade facilitation: In terms of free flow of funds and financial reform and innovation, the pace of opening up the financial industry has accelerated, and thousands of companies have opened accounts. Hainan has become the second region in the country to open a free trade account. This is an important attempt for the internationalization of Hainan's financial industry, providing a channel for powerful companies to go international. In terms of the free flow of goods, Hainan has been optimized on the basis of the standard version of the international trade single window, forming a single window with unique Hainan characteristics. On March 9, 2019, the Sanya East Coast Area 
Administrative Examination and Approval Bureau officially opened, which also marked the official start of the deepening of the centralized administrative licensing reform in the East Asian area of Sanya. The era of "one seal management approval" is gradually coming. As the core area of Hainan Free Trade Zone, Sanya City undertakes the main task of innovation experiment, transforms government functions, reforms the government's management system and supervision mode, reverses the previous administrative approvalbased management model, and realizes the Hainan government's "distribution service"reform. And this change has been immediately seen in Sanya. Once the matter was transferred to the position, 16 seals were combined into one chapter, and the District Administrative Examination and Approval Bureau transferred 129 administrative licensing items and 85 other administrative power items from 16 departments including development, construction, transportation, and water affairs at one time.The concentration rate of matters reached over $90 \%$, and a seal tube approval was implemented.

3) Tourist entry visa: The opening policy of tourism consumption in Hainan Province was further relaxed. In May 2018, the number of visa-free tourist groups increased from 26 to 59, and the visa exemption time was extended to 30 days. This has greatly enhanced the enthusiasm ofdomestic and foreign tourists to visit Hainan. According to data disclosed by Hainan Tourism official website, as of February 2019, more than 300,000 overseas tourists came to Hainan for visa-free travel, up $13.1 \%$ year-on-year.For overseas tourists, enjoy the same treatment as local residents, enjoy the tax exemption policy for outlying island passengers by boat, and speed up the opening of dutyfree shops so that overseas tourists can enjoy shopping in Hainan. At the same time, the company has been actively introducing the internationally renowned travel companies such as Thomas Cook to open a branch to improve the tourism service capacity of Hainan Province. In 2018, Hainan saw its opening up in the province, the country and the world in one year. Open Hainan is increasingly connected to the world.

4) Multimodal transport "one system": On the basis of the international container multimodal transport waybill, the innovation proposes a multi-modal bill of lading based on container, supports the "one-unit" reform through various financial modes such as bill of lading pledge, insurance and guarantee, and realizes the effective connection between the railway waybill and the bill of lading. The commercial practice of forming a container multimodal bill of lading application lays the foundation for Hainan to promote the construction of the South China Sea International Trade and Logistics Center. Exploring a new model of collective transportation, transportation and supervision, and through cooperation with customs and railway companies in Southeast Asia, will realize a new mode of collection, transportation and supervision, and realize the sharing of cargo positions of Haikou to Southeast Asia and Haikou to Japan and South Korea based on the advantages of free trade ports. At the same time, in order to solve the problem of the contractual unit supervision and the foreign trade enterprise multimodal transport, the Haikou Customs has established a single consumption declaration system and a diversified verification system that are in sync with the enterprise multimodal transport, carried out the centralized domestic sales of bonded goods, and optimized container carry-over, thus greatly simplifying the multimodal transport service procedures of foreign trade enterprises.

\section{ADVANTAGES AND PROBLEMS IN THE DEVELOPMENT OF HAINAN FREE TRADE ZONE}

\section{A. Advantages of Hainan Free Trade Zone development}

1) Location and policy advantages: At the southernmost tip of China, Hainan Province is backed by inland depths and is located at the transportation hub of the Pacific Ocean, the Indian Ocean and the Atlantic Ocean. It is a bridgehead for trade between China and other countries. Hainan Province has a long-term marine location advantage, with its coastline on the coast of 1944.35 kilometers and a sea area of about 2 million square kilometers. At the same time, Hainan Province is adjacent to Southeast Asia and has extensive economic and cultural exchanges with the rest of the world. As the largest special economic zone in China, Hainan Province, with its location advantage, vigorously promotes import and export trade, thus achieving rapid regional economic growth.

As a model area for the development of China's free trade zone in the future, the state has given strong policy support to the construction of the Hainan Free Trade Zone. In April 2018, General Secretary Xi Jinping announced the establishment of the Hainan Island Free Trade Zone on the occasion of the 30th anniversary of the establishment of the Hainan Special Economic Zone. In the same month, the CPC Central Committee and the State Council issued the "Guiding Opinions on Supporting Hainan's Comprehensive Deepening of Reform and Opening-up", clearly defining the pilot content of the existing free trade zone as the main body, and combining the characteristics of Hainan to build a China (Hainan) free trade zone with a 
scope of implementation for the whole Hainan Island. In October of that year, the State Council approved the establishment of the China (Hainan) Free Trade Zone and issued the "China (Hainan) Pilot Free Trade Zone Overall Plan."

2) Regional GDP growth is faster: Hainan's regional GDP has generally increased in the past eight years (see "Fig. 1"). In 2017, Hainan's GDP reached
446.254 billion RMB, 2.16 times that of 2010, and 57.96 times that of the province built in 1988. Per capita GDP also increased from 23,831 RMB in 2010 to $48,430 \mathrm{RMB}$ in 2017 , an increase of $103.22 \%$. In the 30 years of exploration and reform, these figures are a full affirmation of Hainan's economic development achievements.

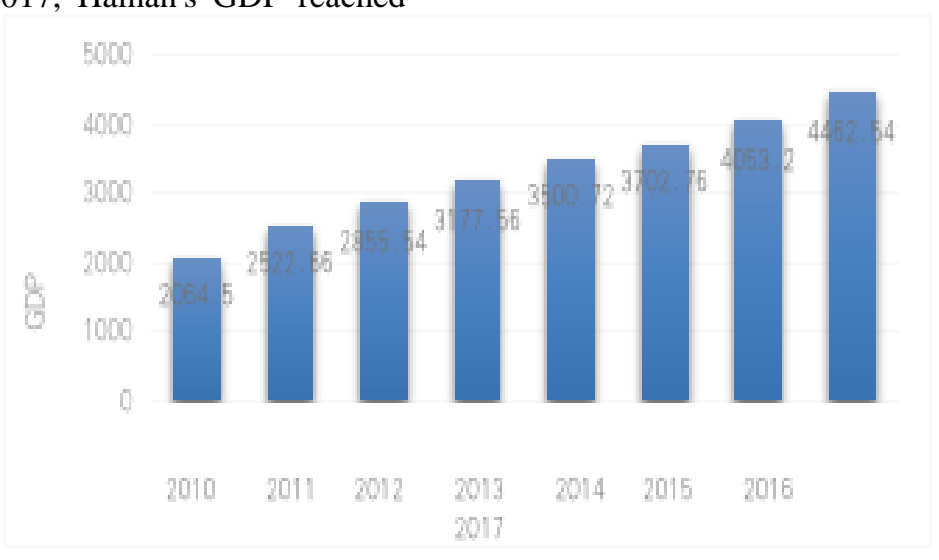

Fig. 1. $2010-2017$ GDP of Hainan Province (Unit: 100 million RMB).

3) Actual use of foreign capital and foreign direct investment rose: Hainan Province is less than other coastal provinces, mainly related to the vigorous development of manufacturing industry since China's reform and opening up. Hainan's manufacturing industry has no comparative advantage, so the economic development is slightly behind.However, as China enters the transition period of manufacturing upgrading and service industry expansion, the next 30 years may be the actual growth period of Hainan. At the same time, Hainan Province also has favorable external conditions, and the growth rate of foreign investment has obviously accelerated. It has increased by $144 \%$ in 16 years, much higher than other regions.From 2010 to 2017, Hainan Province's actual use of foreign direct a. Data source: Hainan statistical yearbook http://stats.hainan.gov.cn/tij/tisu/ndsj/ investment increased steadily (see "Fig. 2"), an increase of $52.51 \%$. In 2017, the actual direct investment in foreign capital was 2.306 billion US dollars, an increase of $8.2 \%$ over the previous year. In 2018, there were 167 new foreign-invested enterprises in the province, an increase of 80 over the previous year. The actual use of foreign capital was 733 million US dollars, an increase of $112.7 \%$. In the process of economic development in Hainan, the investment environment has continued to improve, the degree of openness has been continuously improved, and international cooperation has continued to deepen. The amount of foreign direct investment absorbed by Hainan Province has also increased year by year.

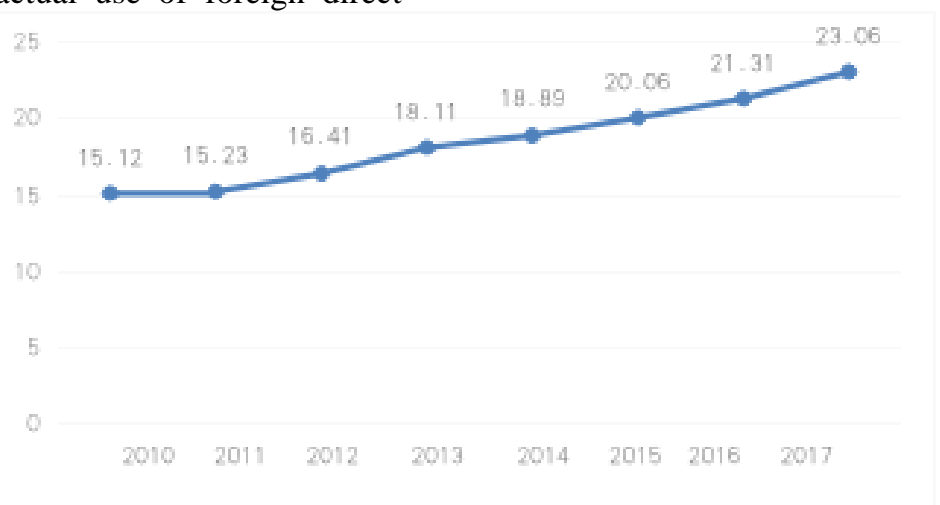

Fig. 2. 2010-2017 the amount of foreign direct investment actually used in Hainan Province (Unit: US \$100 million). 
4) International tourism revenue continues to grow: Hainan's air rights have been opened for 15 years. It has opened Haikou to the Philippines, Cambodia, Vietnam to Haikou, Sanya and other maritime foreign trade routes, and opened 61 direct flights with Russia, Kazakhstan, South Korea and Southeast Asia and many other countries and regions, covering Russia, South Korea, Japan, Vietnam, Thailand, Laos, Cambodia, Singapore, Malaysia, Australia, Italy, Germany and other countries and regions. Thanks to the opening of
Data source: Hainan statistical yearbook http://stats.hainan.gov.cn/tij/ttsu/ndsj/ domestic and foreign trade routes, the source structure of tourists coming to Hainan has been changed, attracting a large number of international tourists. Hainan's inbound tourism revenue, which has been declining since 2011, improved in 2015 (see "Fig. 3"), achieving a restorative growth. In 2018, Hainan ushered in the positioning of the trade zone throughout the year, achieving an international tourism income of 771 million US dollars, an increase of $13.1 \%$.

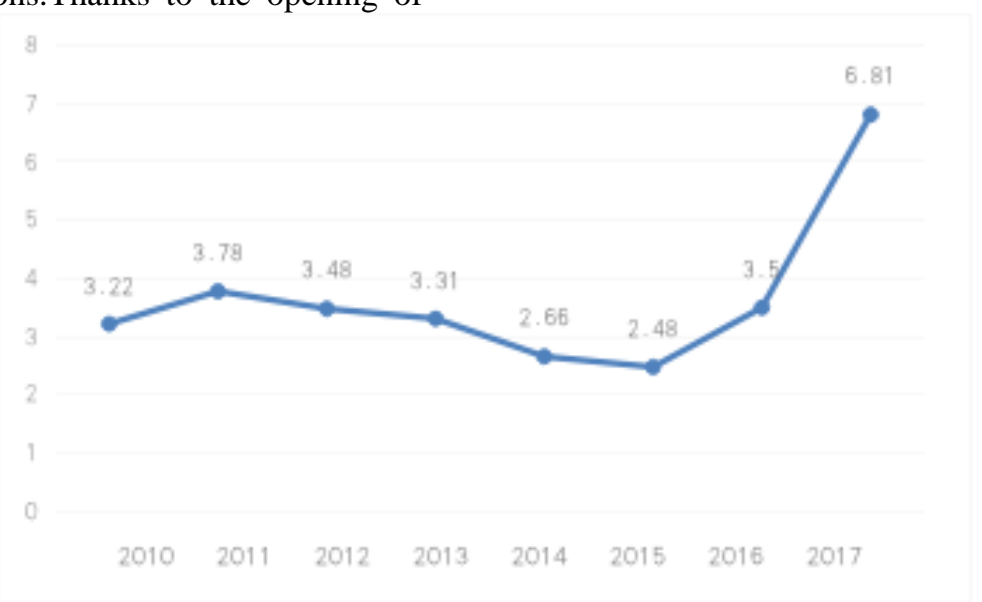

Fig. 3. 2010 -2017 International tourism revenue of Hainan Province (Unit: US \$100 million).

\section{B. Problems in the development of Hainan Free Trade Zone}

1) Business environment needs further improvement: The business environment problem has always been an important issue for domestic and foreign investors to criticize Hainan. On the whole, the social integrity construction in Hainan Province is still relatively backward.According to the data of the 2017 city credit report released by Credit China, in the credit scores of 261 cities surveyed, Hainan's cities are overall lower, and the best performing Sanya score is 82.31, ranking 15th. According to the "Sanya High-priced Seafood Event" that occurred in September 2017, it has exposed many shortcomings in Hainan's urban credit construction. At the same time, Hainan's economy is small, the supply of professional services is insufficient, and there are fewer organizations that can provide professional services. With the in-depth development of Hainan Free Trade Zone, the entry of domestic and foreign enterprises will inevitably lead to imbalances in supply and demand of professional services. In addition, there are serious administrative examinations and approvals in Hainan Province. Although the trade
Data source: Hainan statistical yearbookhttp://stats.hainan.gov.cn/tjj/tjsu/ndsj/ facilitation is actively promoted and the administrative examination and approval procedures are streamlined, in reality, there are still many problems of high approval items and high institutional transaction costs.

2) Low import and export trade: As global trade protectionism continues to heat up, the international economic and trade situation has intensified. This has had a profound impact on the import and export trade of Hainan Province. According to "Fig. 4", since 2015, the scale of import and export trade in Hainan Province has shown a downward trend. In 2017, the import and export volume of Hainan Province was 70.27 billion $\mathrm{RMB}$, a year-on-year decrease of $6.47 \%$. The total value of exports was 29.566 billion RMB, up $110.4 \%$ year-on-year; the total value of imports was 40.706 billion RMB, down $33.36 \%$ year-on-year.From 2010 to 2014 , the overall increase slowly. In 2015, there was a substantial increase in export-oriented economic production and operation. The import value of key imported products and the export value of superior products maintained growth. Only in 2017, the export and import prices showed opposite directions. Importoriented trend may change slowly. 


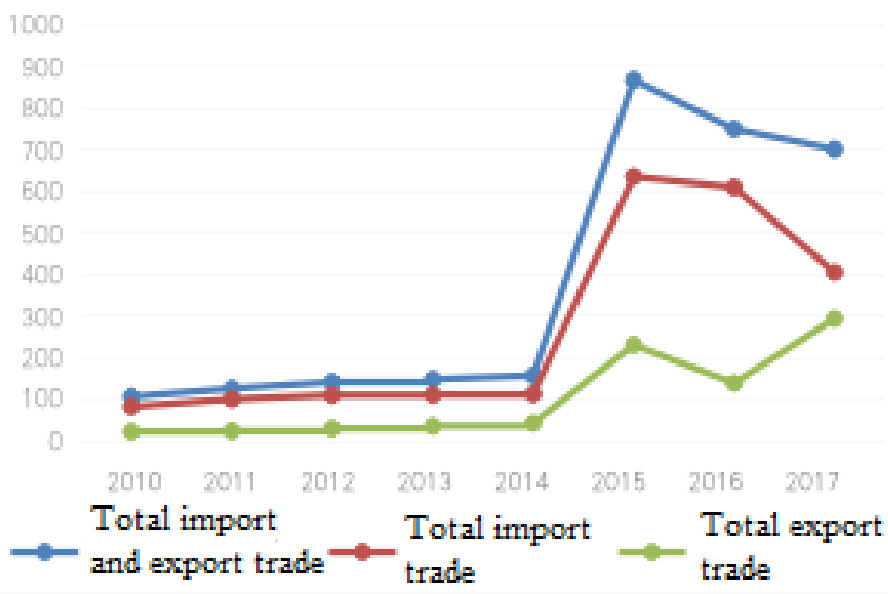

Fig. 4. 2010 -2017 Import and export trade of Hainan Province (Unit: US \$100 million).

3) Unreasonable industrial structure, urgently need to be upgraded and upgraded: Hainan's industrial structure is unreasonable and there are few high-tech industries. In 2017, the first, second and third industries accounted for $20.7 \%, 32.7 \%$ and $46.6 \%$ respectively.Compared with coastal provinces such as Guangdong, Zhejiang and Fujian, the development level of Hainan's service industry and circulation industry is still low, which is extremely unfavorable for the development of free trade zone. Hainan Province has a low level of technology, a low-end technology industry, and a weak industrial base. At the same time, their own high-educational ability is also weak, unable to attract a large number of high-quality talents to come to Hainan. The lack of technology and talent will lead to further deterioration of the unreasonable industrial structure of Hainan Province, and the added value of the industry cannot be improved, which is not conducive to its international trade.

4) Insufficient supply of internationalized products and services: Hainan Province has rich tourism resources and location transportation advantages, and has unique advantages in building an international tourism consumption service center. However, the current problem is that Hainan Province is unable to provide international products and services that cannot meet the needs of domestic and foreign consumers. Chi Fulin, dean of the China (Hainan) Reform and Development Research Institute, pointed out that in the third quarter of 2018, the per capita consumption of overnight visitors in Hainan was 814.85 RMB, of which the basic consumption ratio was $71.04 \%$, and the consumption of shopping, entertainment and other services was only $19.79 \%$ [10]. This set of data shows that there are few types of services that tourists can a. Data source: Hainan statistical yearbook http//stats hainan gov $\mathrm{cn} / \mathrm{tij} / \mathrm{tj}$ su/ndsj/ enjoy in Hainan, mostly concentrated on basic consumption such as catering, accommodation, scenic spots, etc., and relatively little for derivative consumption such as shopping and entertainment.

\section{HaInAN Free Trade ZONE DEVELOPMENT PROSPECTS}

\section{A. Functional positioning and development model}

In recent years, Hainan Free Trade Zone has been continuously striving to improve the conditions of economy, transportation and opening up, and to provide impetus for the efficient construction and development of Hainan Free Trade Zone. In the free trade pilot zone approved by China, it was found that the early free trade test zones were scientifically formulated based on the local geographic location, and scientifically developed the development direction in line with their own characteristics. The construction of free trade pilot zones in Shanghai, Guangdong, Fujian and Tianjin focuses on each characteristic. As the absolute economic center of China, the orientation of Shanghai's free trade pilot zone is to carry out all-round reform for developed countries in Europe and the United States, even for the whole world; China (Guangdong) transforms through processing trade, emphasizing the liberalization of service trade; China (Fujian), the free trade pilot zone focuses on building high-end service industries and uses regional advantages to strengthen economic and trade cooperation with Taiwan. The China (Tianjin) Free Trade Zone is based on financial leasing business and cooperates with Beijing, Tianjin and Hebei to promote economic transformation in the region. The upgrade, no matter what the initial free trade pilot zone is, the ultimate goal is to create a comprehensive free trade pilot zone, which is the ultimate goal of China's existing free trade pilot zone. 
Based on the location conditions of Hainan Free Trade Zone, it is positioned as "to comprehensively deepen the reform and opening up pilot zone, the national ecological civilization pilot zone, the international tourism consumption center, and the national major strategic service support zone", therefore, Hainan Free Trade Zone should focus on the development of international tourism consumption and comprehensive service trade industries, based on the coastal areas of South China, to build a South China Sea trade center and logistics center, and promote the Southeast Asian trading system centered on Hainan Island, and strive to make it into the highland of China's opening-up, eventually to the direction of building a comprehensive free trade pilot area.

\section{B. Inter-regional cooperation and exchange}

The level of opening up has a significant impact on the economic impact of the Hainan Free Trade Zone. As a node area in South China, Hainan has a certain level of international openness. However, reviewing the declaration process of the free trade pilot zone, the competition between other important provinces and cities in South China and the Hainan Free Trade Zone is obvious. The construction of the Hainan Free Trade Zone needs to be strengthened with the surrounding areas on the premise of maintaining good international openness, and should also strengthen exchanges and cooperation with surrounding areas, especially with the Guangdong region.

At present, in the face of the hottest declaration of free trade pilot zones set up across the country, although Hainan and Guangdong have shown obvious competitive momentum when they declare free trade pilot zones, competition and cooperation can be mutually transformed. The urban agglomerations of the two cities have huge economic aggregates, and each has its own economic characteristics. Therefore, in the future, when facing the same direction and market, the two cities can focus on their respective development priorities. For example, the Guangdong Free Trade Zone is deeply integrated with Hong Kong, Macao and Taiwan to create the Greater Bay Area of Guangdong, Hong Kong and Macao. The Hainan Free Trade Zone is based on its location on the South China Sea, focusing on tourism and service advantages, and positioning its free trade pilot zone as open out-of-island service center and international tourism consumption center. At the same time, further strengthen the supporting work of logistics, information and other infrastructure, strengthen the links between the Hainan and Macao region, and seek common development of both sides.

Strengthening cooperation and complementary advantages between Hainan and Guangdong, and cooperation and communication with Hainan and Guangdong are important guarantees for the future development of Hainan Free Trade Zone to be more efficient and convenient. It is conducive to promoting common development and is more conducive to free trade within the region. The construction of the experimental area will create a better external environment and reduce the resistance of the construction and development of the park. In addition, on the basis of strengthening cooperation with the Guangdong Free Trade Pilot Zone, the Hainan Free Trade Zone should actively explore emerging markets and seek cooperation with neighboring countries and regions, especially with the South China Sea countries. It is possible to jointly negotiate with each other and establish a good situation of mutual complementarity and common development, which is conducive to the development of the regional economy, the gradual realization of institutional innovation and further improve the level of opening up under a higher level and more advanced economic environment of Hainan Free Trade Zone.

\section{Optimization of the business environment}

First of all, in terms of trade, we should focus on promoting trade transformation and upgrading, focusing on building a "single window". That is to say, from the complex process of submitting materials to multiple windows, to the transformation of only providing the documents and data reports required by import and export trade, which greatly accelerates the speed of customs clearance of import and export trade, so as to enhances the function of transport services in the region, and then forms the advantage of the free trade pilot zone for foreign trade development; in terms of investment, a good investment method and investment environment are the key to attracting foreign investment in the region. The Hainan Free Trade Zone should focus on the construction of investment policies. We can improve the level of investment in the free trade pilot zone by reducing the threshold of foreign investment access, attracting more foreign investment. Through the implementation of the filing system for foreign investment projects, the deepening of the reform of the registration system for business affairs, and the promotion of the reform of "license before certificate", the investment level of the free trade pilot zone will be improved.

Second, we will continue to develop the international tourism industry and create a bright spot for economic growth. We will make full use of the visafree policy for the 59 countries in Hainan Free Trade Zone to attract more tourists to the Hainan Free Trade Zone. We will also improve the tax-free shopping policy on the outlying islands, optimize commodity prices, enrich commodity brands, improve the service level of new duty-free shops, and liberalize the introduction of foreign talents, especially the family service personnel of hotel management personnel, etc., 
to promote the development of tourism in Hainan. It has stimulated economic growth and further exerted the policy effect to help build the international tourism consumption center.

Finally, we attach importance to the financial sector, especially in terms of institutional innovation and openness. In contrast, Shanghai, the development goal of the Shanghai Free Trade Zone clearly proposes the content of currency freely convertible. To implement this development goal, the Shanghai Free Trade Zone gradually pilots the convertible business of RMB capital projects in order to expand the circulation of RMB across domestic and overseas markets and expand financial services. The scope of opening up to the outside world will further provide impetus for the subsequent development of the Shanghai Free Trade Zone in terms of financial classification. In the future, for the construction of the Hainan Free Trade Zone, the first is to control the risk within the scope of safety. Second, the reform measures such as the implementation of the free trade zone, the marketization of interest rate policies of financial institutions such as banks, and the convenient flow of funds across borders will be strengthened. Financial services functions in the district, specifically, we can further improve the financial market trading platform, gradually open up foreign companies to participate in commodity futures trading channels, and encourage financial markets to carry out product innovation. Third, Hainan Free Trade Zone can also learn from Guangdong, Tianjin, Fujian Free Trade Zone measures. Foreign enterprises can have a certain amount of independent exchange rights in investment, mergers and acquisitions, debt instruments and financial investment transactions.

\section{Reconstruction of the Free Trade Zone supervision system}

As we all know, the biggest feature of the free trade pilot zone is "freedom" and "trade". By rationally relaxing the control in the zone, it creates a free and convenient environment for enterprises, which is conducive to raising the level of openness and trade. In the process of government transformation of economic regulation, it is necessary to draw on the experience of various free trade parks. The United States, Singapore and other free trade zones implement electronic declaration of foreign trade goods, simplifying the handling of customs declaration procedures; in the overall construction plan of the four free trade zones in Shanghai and other places in China, the general regulation on the transformation of government functions and innovative supervision methods is carried out in specific. In terms of reform, all localities have paid attention to decentralizing economic management authority to the park, simplifying procedures, improving administrative transparency, and adopting a negative list management model. At the same time, they implemented a "one-line liberalization" and "secondline efficient management" service model to promote the transformation of government management from focusing on pre-approval to focusing on in-process and post-event supervision.

In summary, the Hainan Free Trade Zone can draw on the development experience of various places in the pilot study of relevant special supervision zones. In terms of innovative supervision mode, Hainan Free Trade Zone can learn from the experience of "first-line thorough opening and second-line efficient management" in Shanghai and other free trade zones, and gradually transform into pre-approval and inprocess review and post-event supervision. "One line release" is the entry of foreign goods into the free trade zone. The customs department is only responsible for filing the type, quantity and value of the goods. The inspection and quarantine department is only responsible for the inspection and quarantine of the goods, thus avoiding the repeated work results in reduced customs clearance efficiency. At the same time, the operation of the district and the port will be implemented, and the goods can be freely circulated. "Second-line high-efficiency management" means that when goods flow between the free trade zone and the domestic non-free trade zone, the customs must levy taxes according to relevant laws and regulations, and at the same time impose strict supervision on the goods in the exit zone to prevent smuggling. At the same time, on the basis of the original legal system, Hainan Province can establish local rules and regulations that are compatible with the development of the free trade zone and national laws and regulations through local legislation, so as to better guide the construction of the park. It is necessary to fully clarify the boundaries between laws and regulations, and clarify that the development of free trade zones is within the scope of allowable, combined with regional characteristics, focus on reform and innovation, through the construction of new free trade zone, we can rationally develop economic trade and realize economic transformation and breakthrough. In the future, the construction of Hainan Free Trade Zone can draw on the "one-stop" declaration and inspection operation system, and reduce the review and quarantine procedures and burdens of enterprises within a reasonable scope of inspection. Relevant departments should change their work concepts, actively promote the reform of "release management service", gradually relax the control of enterprises, and enhance the operational vitality of enterprises, so as to accumulate more experience for the construction of free trade zones in other regions.

\section{CONCLUSION}

Against the background of economic globalization and regional economic integration, economic and trade 
exchanges between countries around the world have become increasingly frequent, and they have actively joined the multi-regional economic cooperation organizations. At this time, the construction of China's free trade park is an inevitable opportunity and challenge. The choice to establish a free trade park is an innovation that promotes economic transformation and institutional development by deciding reforms and reforming the field of experimental reform. Hainan Free Trade Zone is a model area for China to achieve highquality opening up to the outside world. It is also China's largest free trade zone, focusing on the successful construction of Hainan Free Trade Zone, and exerting the role of Hainan Free Trade Zone in the radiation of the South China Sea region, reshaping the South China Sea. The regional economic and trade pattern is of far-reaching significance for China to promote the construction of the Belt and Road. On the whole, the Hainan Free Trade Zone was only one year old, and there are still many problems. However, as a sample of China's future opening up and development, it shoulders a heavy historical mission. Therefore, in the context of a new round of technology and industrial revolution, Hainan Province should make full use of its own advantages and national policy support, and constantly cultivate its own unique competitive advantages, and become the leader of reform and opening up in the new era.

\section{References}

[1] Dobbs L J, Madigan M N, Carter A B, et al. Use of FTA gene guard filter paper for the storage and transportation of tumor cells for molecular testing[J]. Archives of Pathology \& Laboratory Medicine, 2006, 126(1):56-63.

[2] Moscoso H, Alvarado I, Hofacre C L. Molecular analysis of infectious bursal disease virus from bursal tissues collected on FTA filter paper[J]. Avian Diseases, 2014, 50(3): 391-396.

[3] Nan Yan. Problems and Countermeasures in the Construction of China-Russia Free Trade Area[P]. 4th Annual International Conference on Management, Economics and Social Development (ICMESD 2018), 2018.

[4] Zhang Bin, Wang zhan'ao. Empirical analysis on the trade structure effect of China-ASEAN Free Trade Area-Based on the panel data of HS92 commodity classification from 1995 to 2008 [J]. World economic research, 2011 (1): 75-81.

[5] Zhao Liang, Chen Shumei. The "free trade zone driven" of economic growth - a comparative study based on China South Korea Free Trade Zone, China Japan South Korea Free Trade Zone and RCEP [J]. Economic review, 2015 (1): 92-102.

[6] Wang Daojun. The foundation and system innovation of theestablishment of Shanghai Free Trade Zone [J]. Opening guide, 2013 (5): 30-33.

[7] Zhang Youwen. Free Trade Zone experiment and open economic system construction [J]. Academic monthly, 2014 (1): 11-19.

[8] He Li. Practice of coastal and inland free trade zones in South America and construction of free trade zones in China $[\mathrm{J}]$. International business research, 2014, 35 (2): 24-32.
[9] Lin Na, LanBei. Reflections on the establishment of a pilot Free Trade Zone in Chengdu [J]. Journal of the Party School of the CPC Chengdu Municipal Committee, 2014 (2): 65-67.

[10] Chi Fulin. Four suggestions for building Hainan pilot free trade zone with high standards and high quality $[\mathrm{J}]$. Hainan today, 2018, 245 (12): 15-16.

[11] He Weiming. Hainan's construction of free trade zone and free trade port is an inevitable requirement for docking national strategy [J]. New Oriental, 2018, 236 (05): 28-31.

[12] Ding Honglin. Discussion on the construction and development mode of Hainan free trade zone (port) [J]. China water transport, 2018, 600 (11): 20-23.

[13] Wu Shicun, CaiZhenwei. Era background, far-reaching significance and promotion path of Hainan Free Trade Zone Construction [J]. South China Sea journal, 2018, 4 (03): 52-59.

[14] Lu konbiao. Logic, challenges and suggestions on financial opening of Hainan free trade area (port) [J]. Banker, 2018, No.200 (6): $10+62-65$

[15] Ding Honglin. Countermeasures and suggestions for Hainan to build the island wide free trade zone and the world's largest free trade port [J]. China water transport, 2018, 597 (10): 10-12. 